\title{
Tributaries as richness source for Oligochaeta assemblage (Annelida) of Neotropical dammed river
}

\author{
Ragonha, FH. ${ }^{a *}$, Petsch, DK. ${ }^{a}$, Alves, GHZ. ${ }^{a}$, Santana, HS. ${ }^{a}$, Michelan, TS. ${ }^{a}$ and Takeda, AM. ${ }^{b}$ \\ aPrograma de Pós-graduação em Ecologia de Ambientes Aquáticos Continentais - PEA, Universidade Estadual de \\ Maringá - UEM, Av. Colombo, 5790, Jardim Universitário, CEP 87020-900, Maringá, PR, Brazil

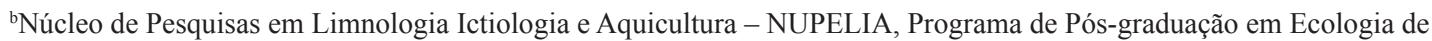 \\ Ambientes Aquáticos Continentais - PEA, Departamento de Biologia - DBI, Universidade Estadual de Maringá - UEM, \\ Av. Colombo, 5790, Jardim Universitário, CEP 87020-900, Maringá, PR, Brazil \\ *e-mail: flaviohragonha@yahoo.com.br
}

Received: April 23, 2013 - Accepted: September 25, 2013 - Distributed: December 31, 2014

(With 6 figures)

\begin{abstract}
Tributaries may serve as richness source for the river main channel and the zoobenthos community is a good tool to verify this kind of pattern. In this study, we aimed to characterize the benthic invertebrate assemblage in three tributaries associated to the Paraná River main channel, focusing in Oligochaeta community. We hypothesized that (i) in tributaries, Oligochaeta are richer than the main river (Paraná River) and (ii) dammed tributary (Paranapanema River) is poorly diverse than the others. Samples were conducted in Paranapanema, Baía and Ivinhema tributaries using a modified Petersen grab along three transects (samples conducted inside the tributary, in the mouth of each tributary and inside Paraná River). To analyze (i) the difference between the richness and density among the tributaries and the Paraná River and (ii) effect of each tributary transect on the Oligochaeta richness we used a nonparametric Kruskal-Wallis test. Changes in environmental variables and in richness and composition of Oligochaeta were summarized by Canonic Correspondence Analysis. It was registered 21 different benthic invertebrates taxa, being Oligochaeta assemblage with the highest density. Within Oligochaeta, Narapa bonettoi was the most abundant species, followed by Haplotaxis aedochaeta and Paranadrilus descolei. In our results we refused both hypotheses, because we did not found significant differences for richness and density between the tributaries and the main river, and also no difference between the three transects of each tributary were found. However, the tributaries less influenced by damming, especially the Baía recorded high richness. This corroborates their importance to diversity in the floodplain and the species of Oligochaeta reflect the peculiar characteristics of habitats within each tributaries.
\end{abstract}

Keywords: Narapa bonettoi, benthic invertebrate, sediments, floodplain, biodiversity.

\section{Tributários como fontes de riqueza para assembleia de Oligochaeta (Annelida) de um rio Neotropical represado}

\section{Resumo}

Tributários podem servir como fonte de riqueza para o canal principal do rio e a comunidade de zoobentos é uma boa ferramenta para verificar esse tipo de padrão. Neste estudo, que teve como objetivo caracterizar as assembleias de invertebrados bentônicos em três tributários associados ao canal principal do rio Paraná, com foco na comunidade de Oligochaeta. Nossa hipótese é que (i) em afluentes a assembleia de Oligochaeta apresenta maior riqueza do que o rio principal (rio Paraná), e (ii) o tributário represado (Rio Paranapanema) é menos diverso do que os demais. As amostras foram realizadas nos tributários Paranapanema, Baía e Ivinhema utilizando uma draga Petersen modificado ao longo de três transectos (amostras realizadas dentro do afluente, na boca de cada afluente e no interior do Rio Paraná). Para analisar (i) a diferença na riqueza e densidade entre os afluentes e o rio Paraná, e (ii) o efeito de cada transecto do tributário sobre a riqueza Oligochaeta foi utilizado um teste de Kruskal-Wallis não paramétrico. Mudanças nas variáveis ambientais e na riqueza e composição de Oligochaeta foram resumidos por análise de correspondência canônica. Foi registrados 21 diferentes táxons invertebrados bentônicos, sendo assembleia de Oligochaeta com a maior densidade. Dentro de Oligochaeta Narapa bonettoi foi à espécie mais abundante, seguido por Haplotaxis aedochaeta e Paranadrilus descolei. Em nossos resultados, ambas as hipóteses foram refutadas, visto que não mostraram diferenças na riqueza e densidade entre os tributários e o canal principal, e nem entre os três transectos dos tributários. Entretanto, os tributários menos influenciados pelo represamento, principalmente o Baía, registraram riqueza elevada. Isso corrobora sua importância para a diversidade na planície de inundação e as espécies de Oligochaeta refletem as características peculiares dos habitats dentro de cada tributátio.

Palavras-chave: Narapa bonettoi, invertebrados bentônicos, sedimentos, planície de inundação, biodiversidade. 


\section{Introduction}

Worldwide, the lotic systems have been altered by the constructions of dams (Boon et al., 1992) and, the aquatic communities are strongly affected by the habitat loss, changes in the flow intensity and alterations in the water chemistry and physical parameters (Barletta et al., 2010). These problems directly affect the bottom fauna causing loss of species, increasing the density and alterations in community structure (Ward and Stanford, 1979).

Large river floodplains are deterministic ecosystems, in which the lateral hydrological connectivity with lakes and tributaries describes the exchanges by water of energy, material and organisms from the main to secondary floodplain channels (Paillex et al., 2012). In natural conditions, these locations are typically characterized by high habitat heterogeneity, high variability in flow, sediment load and sediment size (Ribeiro et al., 2012). For those reasons, the lateral connectivity with tributaries may serve as source of richness for the river main channel.

Nevertheless, many rivers have been channelized and regulated by dams, often with the aim to produce hydroelectric power (Barletta et al., 2010). This kind of anthropic alteration may have consequences downstream the dam such as loss of habitats, changes in physical and chemical conditions, shift in sediment load downstream the dam and sometimes even alter the substrate. Thereby, habitat fragmentation has been implicated as a primary cause underlying the global loss of biodiversity (Primack, 1993) for a variety of freshwater organisms, ranging from producers to consumers.

One group of organisms is especially important, the benthic invertebrate assemblage, because they play an important role in freshwater ecosystems in linking primary production, allochthonous input and top predators (Kagalou et al., 2006). These organisms are very sensitive to physical and chemical disturbances (Furse et al., 2006; Jesús-Crespo and Ramírez, 2011), which lead to reductions in diversity and abundance and increased dominance of species that can tolerate adverse conditions (Smith and Lamp, 2008; Jesús-Crespo and Ramírez, 2011; Wang et al., 2012)

Within benthic invertebrates, Oligochaeta are one of the most abundant groups, in almost all freshwater environments and particularly in the Paraná River floodplain (Takeda, 1999), and have an important role in structuring the sediment of freshwater ecosystems (Drago et al., 2004; Marchese, 2009). Oligochaeta assemblages are influenced by the type of substrate, food availability, and especially the flood pulse (Stevaux and Takeda, 2002; Behrend et al., 2009) and hydro-morphological characteristics (Blettler et al., 2008).

In this study, we aimed to characterize the benthic invertebrate assemblage in four rivers, focusing in Oligochaeta community. We hypothesized that (i) in tributaries, Oligochaeta are richer than the main river (Paraná River) and (ii) tributary which is influenced by dams (Paranapanema River) is poorly diverse than the others. According to these hypotheses we tested the predictions that (i) tributaries have different granulometric texture and high amount of organic matter than the main river, which leads to a more complex habitat reflecting in a more diverse community and (ii) the dam alter abiotic conditions diminishing the local diversity.

\section{Material and Methods}

\subsection{Study area}

This study was conducted in the Paraná River main channel (in a floodplain) and three tributaries (Figure 1). The tributaries sampled are Paranapanema, Baía and Ivinhema River (Figure 1). The difference between them is that only Paranapanema River is dammed, with 7 dams over 10 meters depth (Agostinho et al., 2004). Baía and Ivinhema tributaries do not have dams, and it is very important feature because they keep its natural flow, converging in high habitat heterogeneity and different types of sediment when compared to dammed rivers (Agostinho and Zalewski, 1996). Those kinds of rivers have highlighted the importance for the maintenance of biodiversity.

The tributaries sampled are Paranapanema, Baía and Ivinhema River (Figure 1). The difference between them is that only Paranapanema River is dammed, with 7 dams over 10 meters depth (Agostinho et al., 2004). Baía and Ivinhema tributaries do not have dams, and it is very important feature because they keep its natural flow, converging in high habitat heterogeneity and different types of sediment when compared to dammed rivers (Agostinho and Zalewski, 1996). Those kinds of rivers have highlighted the importance for the maintenance of biodiversity.

\subsection{Sampling procedure}

Samples were conducted on March, 2013 using a modified Petersen grab $\left(0.0345 \mathrm{~m}^{2}\right)$ along three transects in the tributaries Paranapanema, Baía e Ivinhema of Paraná River. The samples were taken in three transects of each tributary (T1, T2 and T3). T1 represent samples conducted inside the tributary (500 $\mathrm{m}$ from the mouth), T2 samples conducted in the mouth of each tributary and T3 samples inside Paraná River (500 m from the mouth of each tributary) (Figure 1). In each transect were taken four benthic samples at right and left margins (RM and LM) and in the center (C), which included three for biological analysis and one for grain size analysis. Each sample was constituted by three subsamples.

Granulometric textures were determined using methodology modified of Wentworth (1922) and the organic matter (O. M) content was obtained from $10 \mathrm{~g}$ sediment by incineration at $560^{\circ} \mathrm{C}$ during four hours.

Along with biological samples, we measured conductivity ( $\mu \mathrm{S} . \mathrm{cm}^{-1}$; portable condutivimeter of Digimed), $\mathrm{pH}$ ( $\mathrm{pHmeter}$ of Digimed), turbidity (NTU; Turbidimeter of Quimis, model Q-179), depth (Ecosonda Hondex PS 7), temperature $\left({ }^{\circ} \mathrm{C}\right)$ and dissolved oxygen $\left(\mathrm{mg} . \mathrm{l}^{-1}\right.$; portable oximeter with YSI equipament) in situ in the bottom region.

Samples for biological analysis were washed through a series of sieves (mesh size from 2.0 to $0.2 \mathrm{~mm}$ ). All organisms 
retained on 2.0 and $1.0 \mathrm{~mm}$ sieves were immediately picked out. The material retained on the $0.2 \mathrm{~mm}$ sieve was fixed in $80 \%$ alcohol and sorted under a stereoscopic microscope. All the invertebrates were identified and counted using the keys Pérez (1988) and Mugnai et al. (2010).

Oligochaeta specimens were identified to species level when mature and to family level when immature due to the need for sexual characteristics for identification, according to the following literature: Brinkhurst and Jamieson (1971), Brinkhurst and Marchese (1991) and Righi (1984).

\subsection{Statistical analysis}

First we characterize the benthic invertebrate assemblage, after that we focus in Oligochaeta group. Oligochaeta abundances were transformed to density (number of individuals*0.0345 $\mathrm{m}^{-2}$ ). To see Oligochaeta assemblage in each transect, Richness (S), Density and Kownacki's dominance index (Kownacki, 1971) were calculated.

The nonparametric Kruskal-Wallis test to analyze the difference between tributaries and Paraná River on Oligochaeta richness and density. This analysis was performed to see the effect of each tributary (transects $\mathrm{T} 1, \mathrm{~T} 2$ and T3) on the Oligochaeta richness. We used the program STATISTICA 7.0, to perform all analysis above.
In order to summarize the relation between the Oligochaeta assemblages with the water physical and chemical data, a Canonical Correspondence Analysis (CCA) was performed using program Pcord5.

\section{Results}

\subsection{Abiotic analysis}

Were founded the highest values of coarser sediments in transects of Paranapanema tributaries (Figure 2A), such as gravel and coarse and medium sand. The highest values of finer sediments (very fine sand and mud) were recorded in transects of the Baía and Ivinhema tributaries, except in T3 of Ivinhema, where registered high values of coarse and medium sand, characteristic for belonging to Paraná River. Was verified in transects of Paranapanema the lowest values of organic matter (\%), while in transects T2 from Baía and T1 from Ivinhema we recorded the highest values (Figure 2B).

The Baía tributary, a semi lotic river, differs from others because the low values of dissolved oxygen, turbidity, electric conductivity and depth (Table 1).

The total of 9.378 benthic invertebrates individuals was recorded, distributed in 21 different taxa (Figure 3A), with

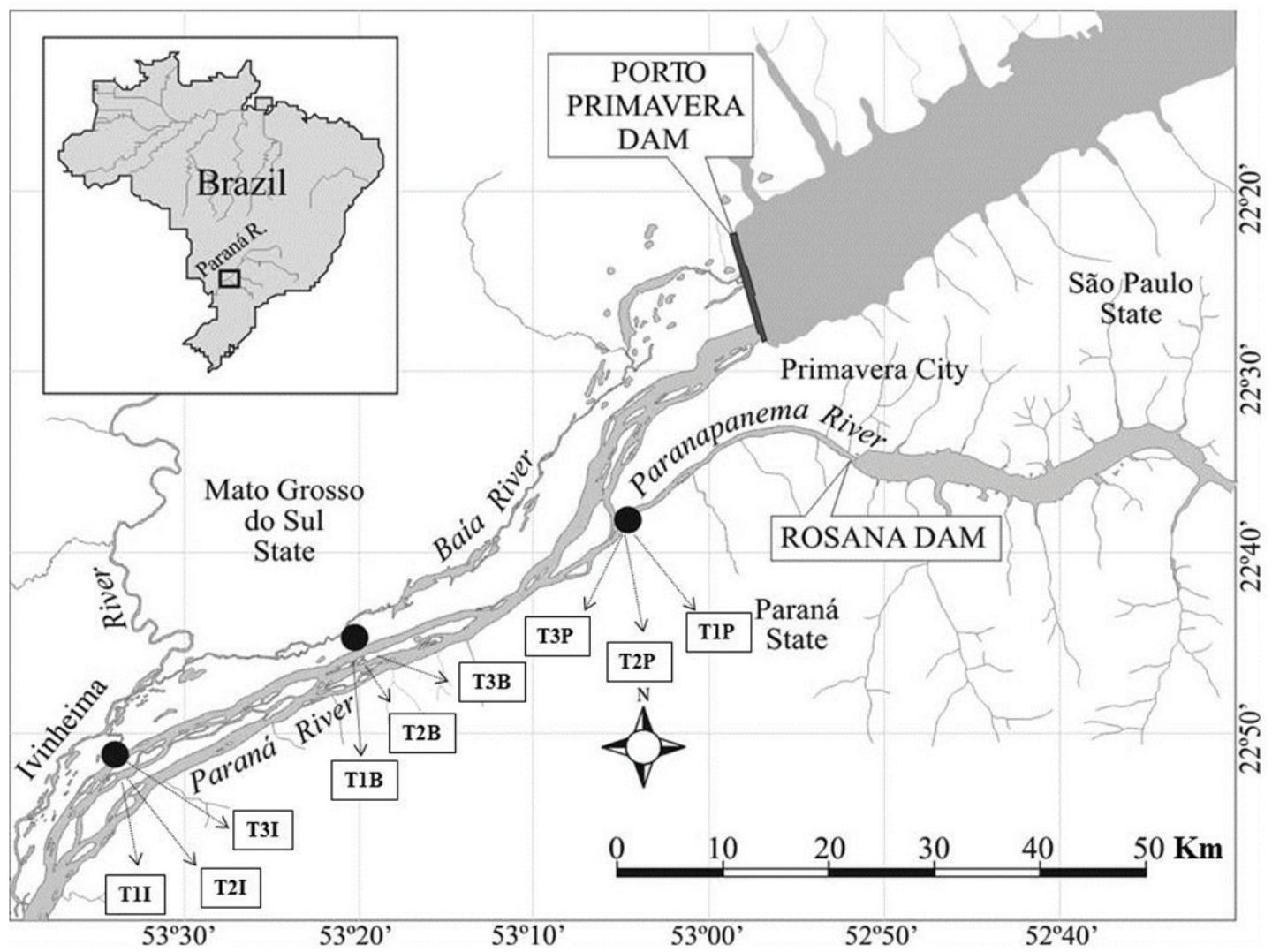

Figure 1. Study area showing the Paraná River and three tributaries (Paranapanema River- P; Baía River - B and Ivinhema - I River) associate to it. The black circles are the sample sites (T1 represent samples conducted inside the tributary $(500 \mathrm{~m}$ from the mouth), T2 samples conducted in the mouth of each tributary and T3 samples inside Paraná River (500 m from the mouth of each tributary). 

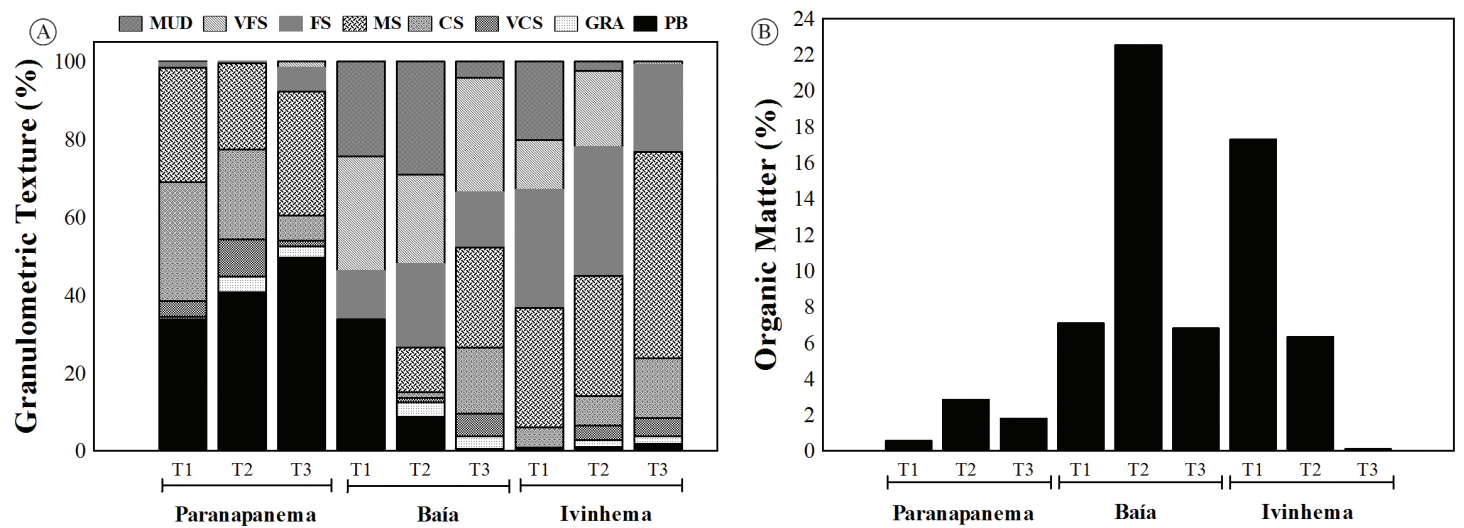

Figure 2. Granulometric composition (A) and Organic matter (B) in the sediment from the tributaries of Paraná River. $\mathbf{V F S}=$ very fine sand; $\mathbf{F S}=$ fine sand; $\mathbf{M S}=$ medium sand; $\mathbf{C S}=$ coarse sand; $\mathbf{V C S}=$ very coarse sand; $\mathbf{G R A}=$ granules; $\mathbf{P B}=$ pebbles.

Table 1. Means of Abiotic variables in sampled transects (T1, T2 and T3) of Paranapanema, Baía and Ivinhema tributaries.

\begin{tabular}{|c|c|c|c|c|c|c|c|c|c|}
\hline & \multicolumn{3}{|c|}{ Paranapenema } & \multicolumn{3}{|c|}{ Baía } & \multicolumn{3}{|c|}{ Ivinhema } \\
\hline & T1 & T2 & T3 & T1 & $\mathbf{T} 2$ & T3 & T1 & T2 & T3 \\
\hline Dissolved Oxygen (mg/L) & 6.45 & 6.34 & 6.79 & 3.91 & 4.10 & 6.24 & 6.11 & 5.96 & 6.73 \\
\hline Oxigygen $(\%)$ & 83.77 & 82.63 & 89.33 & 51.63 & 54.43 & 81.93 & 85.80 & 78.40 & 88.47 \\
\hline $\mathrm{pH}$ & 7.60 & 7.78 & 7.83 & 6.29 & 6.39 & 7.46 & 7.38 & 7.40 & 7.79 \\
\hline Electric condutivity $\left(\mu \mathrm{S} \mathrm{cm}^{-1}\right)$ & 58.10 & 58.20 & 63.50 & 25.33 & 25.07 & 51.70 & 44.30 & 44.53 & 58.37 \\
\hline Temperature $\left({ }^{\circ} \mathrm{C}\right)$ & 29.00 & 29.10 & 29.63 & 29.80 & 29.63 & 29.67 & 29.63 & 29.70 & 29.40 \\
\hline Turbidity (NTU) & 12.50 & 12.60 & 5.03 & 1.47 & 1.81 & 0.40 & 20.77 & 20.53 & 4.68 \\
\hline Depth $(\mathrm{m})$ & 4.80 & 6.43 & 5.07 & 2.60 & 1.53 & 2.50 & 5.67 & 5.47 & 3.97 \\
\hline
\end{tabular}

predominance of Oligochaeta (6.600 individuals) followed by Chironomidae and Harpacticoida groups (Figure 3B).

As Oligochaeta was the most abundant benthic group, we performed further studies focusing on its assemblage (Figure 4A). Regarding the average density, Narapa bonettoi was the most abundant species (Figure 4B). Haplotaxis aedochaeta and Paranadrilus descolei were also relatively abundant and common in the environments analyzed, while the other species were rare and had more restricted occurrence (Figure 4A).

The pattern of richness and density of Oligochaeta assemblage was analyzed in relation to transects without considering the tributary. The density was higher in T3, but not richness, while T1 and T2 were a little more similar. Nevertheless, according to Kruskall-walis test, no differences between the transects were found (Richness: $\mathrm{H}_{(2.9)}=0.83 ; \mathrm{p}=0.66$ - Density: $\left.\mathrm{H}_{(2.9)}=0.62 \mathrm{p}=0.73\right)$.

In general, the mean richness of Oligochaeta was relatively low in the transects (Figure 5). Among the tributaries, the highest mean richness was recorded in Baía River, although no significant differences were found between all the sites $\left(\mathrm{H}_{(8.81)}=14.9 ; \mathrm{p}=0.06\right)$.

Regarding to Dominance index of Kownacki, N. bonettoi was dominant in three sites of Paranapanema and T3 of Baía and Ivinhema tributaries. Paranadrilus descolei was dominant in T1 and T2 of Baía and Ivinhema Rivers, while Aulodrilus pigueti was dominant only in T1 from Ivinhema River (Table 2).

The two first axes of CCA explained $38.6 \%$ of total data variability (axis $1=28 \%$ and axis $2=10.6 \%$ ). The first axis splitted Paranapanema from the others, which was influenced by $N$. bonettoi e H. aedochaeta. Some sites of Baía River were influenced by $\mathrm{pH}$ and organic matter, and by the species Dero (Dero) sawayai, Nais communis, Pristina leydi and Haemonais waldvogeli. Many species, such as A. pigueti, $P$. descolei, Pristina americana, Limnodrilus hoffmeistei, Dero (Aulophorus) furcatus, Dero (Aulophorus) borelli, Pristina aequiseta and Slavina evelinae were related to finer sediment, fine and very fine sand and mud, conditions found in some sites of Baía and Ivinhema rivers (Figure 6).

\section{Discussion}

In our results we refused the initial hypotheses, because we did not found significant differences for richness and density between the tributaries and the main river and, although the low richness in Paranapanema River, this difference was also not significant related to the others tributaries (Baía and Ivinhema).

The higher density of Harpacticoida in the sample site T3 from Baía River is supported by Takeda et al. (2001a). They characterized this group as typical from 
lotic environments like the Paraná River. In the other hand, Chironomidae and Oligochaeta are recognized as the most abundant groups in all different kinds of habitats from the Upper Paraná River floodplain (Higuti and Takeda, 2002; Rosin et al., 2009), and were also abundant in our study.
Oligochaeta was the most abundant group in Paranapanema and Ivinhema tributaries, composed mainly by the following species: $N$. bonettoi, $P$. descolei and $H$. aedochaeta. The dominance of $N$. bonettoi in all transects of Paranapanema and in the sample site T3 of

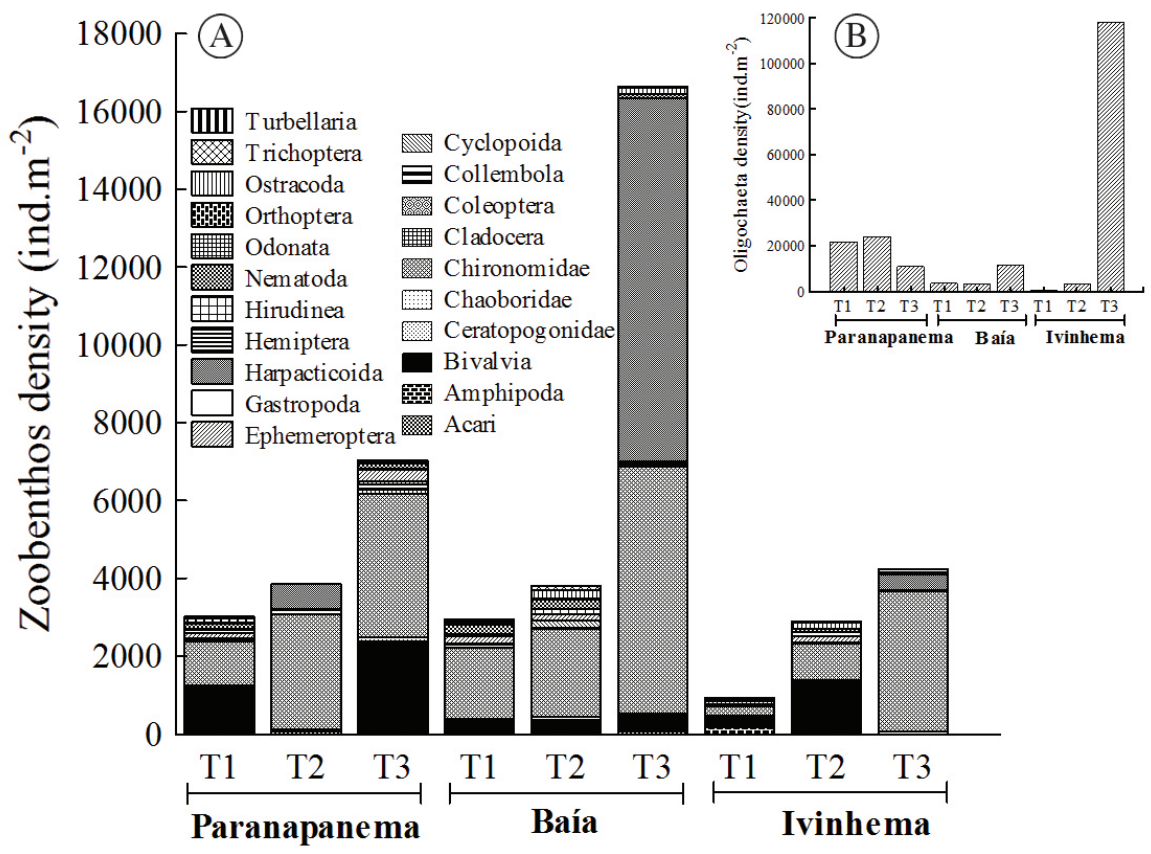

Figure 3. Density of benthic invertebrates community (A) and Oligochaeta assemblage (B). T1 represent samples inside the tributary (500 m from the mouth), T2 samples in the mouth of each tributary and T3 samples inside Paraná River (500 m from the mouth of each tributary).

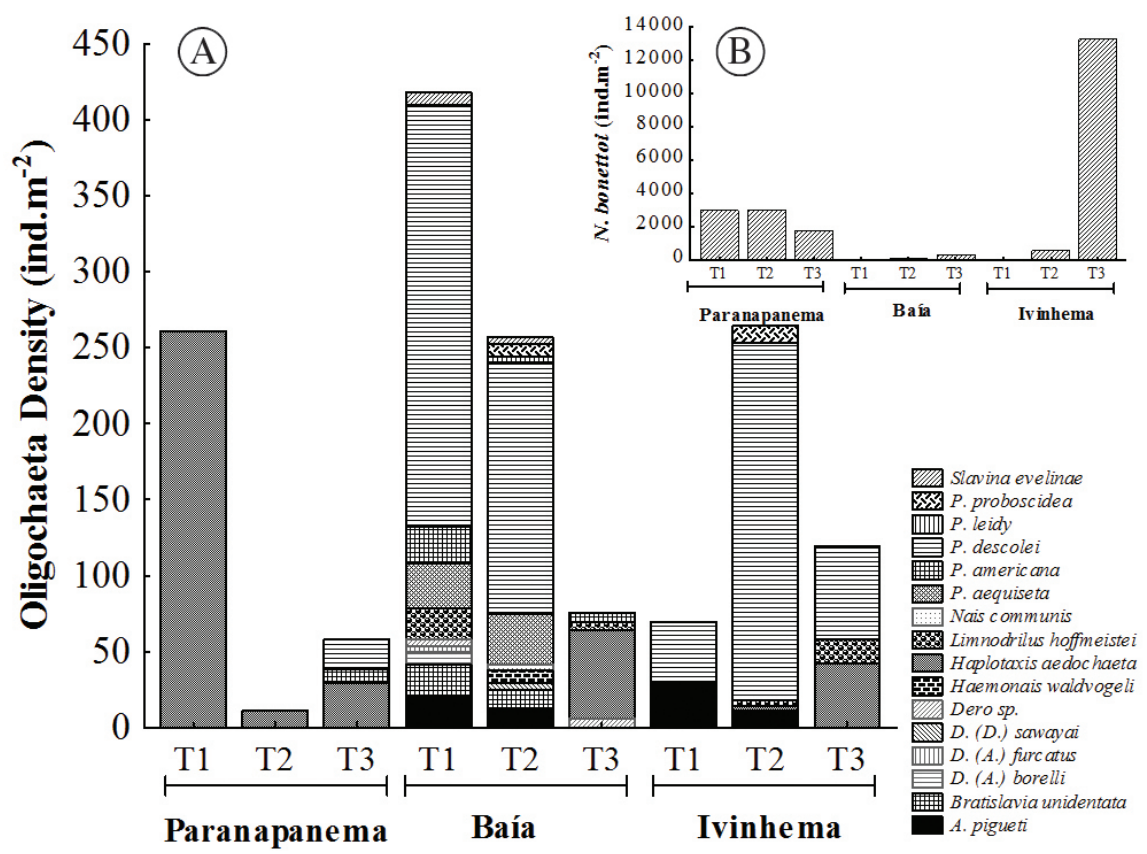

Figure 4. Density of Oligochaeta assemblage without Narapa bonettoi (A) and only Narapa bonettoi (B). T1, T2 and T3, see Figure 1. 
Table 2. Dominance index according Kownacki (1971): Dominants (10-100); Subdominants (1-9.99); Adominants (0-0.99) Adominants A (0.1-0.99); Adominants B (0-0.099).

\begin{tabular}{|c|c|c|c|c|c|c|c|c|c|}
\hline \multirow[b]{3}{*}{ Oligochaeta assemblage } & \multicolumn{9}{|c|}{ Tributaries } \\
\hline & \multicolumn{3}{|c|}{ Paranapanema } & \multicolumn{3}{|c|}{ Baía } & \multicolumn{3}{|c|}{ Ivinhema } \\
\hline & $\mathrm{T} 1$ & $\mathrm{~T} 2$ & T3 & $\mathrm{T} 1$ & $\mathrm{~T} 2$ & T3 & $\mathrm{T} 1$ & $\mathrm{~T} 2$ & $\mathrm{~T} 3$ \\
\hline \multicolumn{10}{|l|}{ Narapidae } \\
\hline Narapa bonettoi - (Righi \& Varela 1983) & 70.76 & 87.68 & 53.22 & & 2.79 & 17.67 & & 7.33 & 87.21 \\
\hline \multicolumn{10}{|l|}{ Haplotaxidae } \\
\hline $\begin{array}{l}\text { Haplotaxis aedeochaeta -(Brinkhurst \& } \\
\text { Marchese 1987) }\end{array}$ & 1.78 & 0.04 & 0.18 & & & 1.67 & & 0.05 & 0.14 \\
\hline \multicolumn{10}{|l|}{ Naididae } \\
\hline \multicolumn{10}{|l|}{ Pristininae } \\
\hline Pristina aequiseta -Bourne, 1891 & & & & 1.52 & 4.96 & & & & \\
\hline Pristina americana-Cernosvitov, 1925 & & & 0.06 & 1.31 & & 0.17 & & & \\
\hline Pristina leidy -Smith, 1896 & & & & & 0.15 & & & & \\
\hline Pristina proboscidea -Beddard, 1896 & & & & & 0.31 & & & 0.15 & \\
\hline \multicolumn{10}{|l|}{ Naidinae } \\
\hline Bratislavia unidentata -(Harman, 1973) & & & & 1.09 & 0.93 & & & & \\
\hline $\begin{array}{l}\text { Dero (Aulophorus) borelli -Michaelsem, } \\
1900\end{array}$ & & & & 0.44 & & & & & \\
\hline $\begin{array}{l}\text { Dero (Aulophorus) furcatus -(Müller, } \\
\text { 1773) }\end{array}$ & & & & 0.22 & & & & & \\
\hline Dero (Dero) sawayai -Marcus, 1943 & & & & & 0.15 & & & & \\
\hline Haemonais waldvogeli -Bretscher, 1900 & & & & & 0.31 & & & & \\
\hline Nais communis -Piguet, 1906 & & & & & 0.15 & & & & \\
\hline Slavina evelinae -(Marcus, 1942) & & & & 0.44 & 0.15 & & & & \\
\hline Dero sp. & & & & 0.22 & & 0.17 & & & \\
\hline \multicolumn{10}{|l|}{ Tubificinae } \\
\hline Limnodrilus hoffmeistei -Claparede, 1862 & & & & 1.09 & & 0.17 & & 0.05 & 0.03 \\
\hline Aulodrilus pigueti -Kowalewski, 1914 & & & & 1.09 & 0.93 & & 13.75 & 0.30 & \\
\hline Paranadrilus descolei-Gavrilov, 1955 & & & 0.12 & 14.59 & 27.89 & & 19.25 & 19.59 & \\
\hline Richness & 2 & 2 & 4 & 10 & 11 & 5 & 2 & 6 & 2 \\
\hline
\end{tabular}

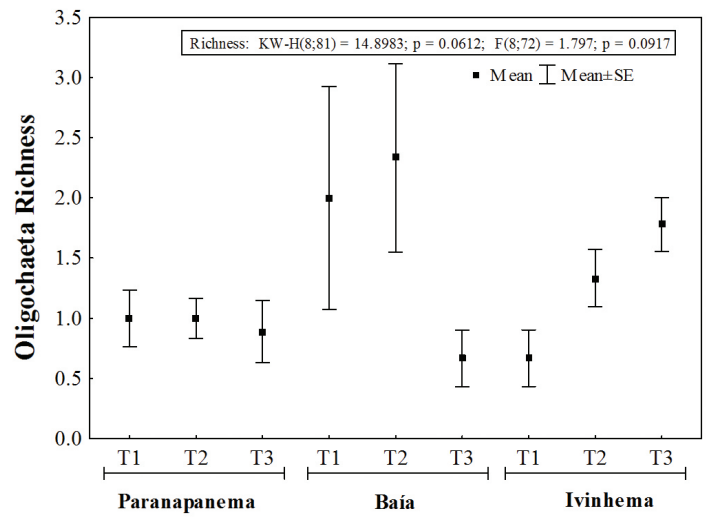

Figure 5. Richness of Oligochaeta assemblage. T1, T2 and T3, see Figure 1.

Ivinhema tributary was explained by abiotic conditions typically of lotic environments, with high values of dissolved oxygen and electric conductivity and granulometric texture composed predominantly of pebbles, coarse and medium sand and very low organic matter content.
The high density of $N$. bonettoi near the Ivinhema tributary is justified by the presence of sand banks in this region, which has less influence of the Porto Primavera dam.

According to Drago (1980), Marchese (1987, 1994), Marchese and Drago (1992), Righi and Varela (1983) and Takeda et al. (2001b), N. bonettoi is a small Oligochaeta species without setae, which lives in the interstices between sand grains in large fluvial systems. Its existence has been reported in lotic water bodies with high current velocities, depths and discharges and sandy mobile sediments with scarce organic matter content, low conductivity and dune beds, and is often the only benthic species in the Paraná River main channel and the principal secondary streams of its alluvial plain.

The second most abundant species, $P$. descolei, is associated with high conductivity, moderate velocity of current, mud-clay and mud-sand substratum (Marchese, 1987; Takeda, 1999; Behrend et al, 2009). This specie was very abundant in our samples, and it was registered in Baía (T1 and T2) and Ivinhema (T1 and T2) tributaries, sites with presence of fine grained sediments, like mud and sand. Low abundance of $P$. descolei in Paranapanema tributary 


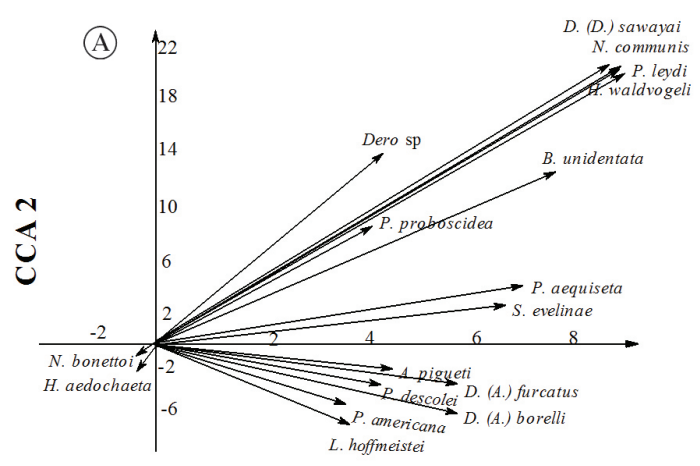

CCA 1

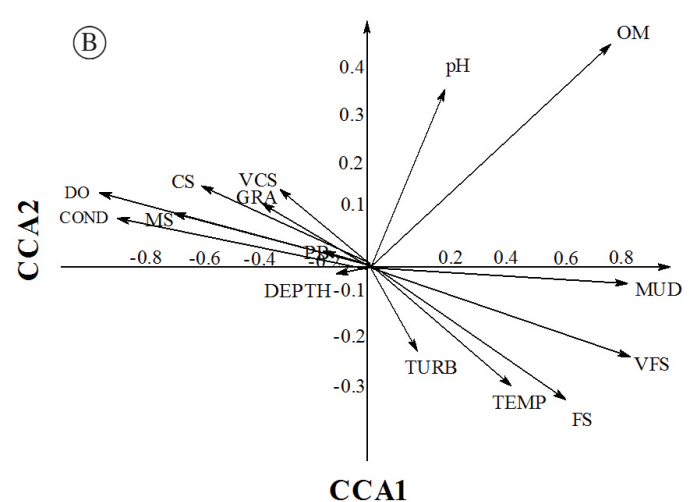

(C)

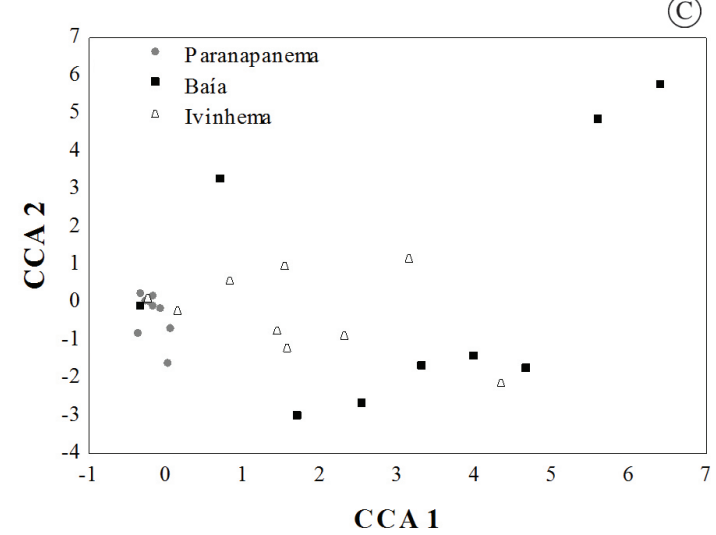

Figure 6. Ordination diagram for the first two axes of Canonical Correspondence Analysis (CCA) with the scores ordination of 1 and 2 axes of sampled sites with the correlation of abiotic variables and Oligochaeta. (A) Species of Oligochaeta (B) Abiotic variables $(\mathbf{C})$ Environments. PB= pebbles; GRA= Granules; VCS= very coarse sandy; $\mathbf{C S}=$ coarse sandy; $\mathbf{M S}=$ medium sandy; $\mathbf{F S}=$ fine sand; $\mathbf{V F S}=$ very fine sandy; $\mathbf{O M}=$ organic matter; $\mathbf{D O}=$ dissolved oxygen; $\mathbf{C O N D}=$ water conductivity; $\mathbf{T U R B}=$ turbidity; $\mathbf{T E M P}=$ temperature.

and T3 of Baía and Ivinhema tributaries occur because it is a large species with no adaptations to environments with strong flow and few organic matters.

Haplotaxis aedochaeta was registered mainly in the Paranapanema tributary, which is characterized by low quantities of organic matter and high amounts of sand and pebbles. Similar observations were reported by MontanholiMartins and Takeda (1999) in the Upper Paraná River, in which they related $H$. aedochaeta to environments with medium, coarse and very coarse sand, gravel and pebbles. Moreover, this species was found in the samples sites T3 from Baía and Ivinhema tributaries (located in the Paraná River) which have similar physical and chemical characteristics to the Paranapanema tributary.

There were no significant differences for richness, but nine of the overall species occurred in the sample sites T1 and T2 of Baía tributary: P. aequiseta, P. leidy (Pristininae), B. unidentata, D. (A.) borelli, D. (A.) furcatus, D (D.) sawayai, $H$. waldvogeli, N. communis and S. evelinae (Naidinae). These species reflected the semi-lentic conditions of this tributary, where features as high levels of organic matter, very fine sand and mud favored the establishment of these species, which was demonstrated by the CCA correlations.
Although the results showed that the tributaries did not affect on the presence of Oligochaeta species on the main river, it was observed differences in the granulometric texture composition and in the water physical chemical variables between each tributary. Thus, the community composition varied along with the availability of habitat, sediment texture and amount of organic matter.

Our results revealed the importance of the tributaries as source of richness to the maintenance of the regional diversity, once that each tributary has peculiar features to Oligochaeta species, as the species $P$. descolei which was abundant in the Paraná River before impoundment, as locals (T3) of three tributaries. Nevertheless, Baía tributary, a semi-lentic ecosystem showed high species diversity, favoring Oligochaeta assemblage colonization.

This study showed the importance of the maintenance of tributaries without dams to Oligochaeta assemblage and for the floodplain biodiversity. The results demonstrated that Oligochaeta assemblage shifts inside each tributary according with its habitats compositions and how the physical and chemical modifications caused by the dam Porto Primavera favors the dominance of species adapted reducing the richness of these locations changed. 


\section{Acknowledgments}

The authors thanks the financial support from the Program of Pós-Graduação em Ecologia de Ambientes Aquáticos Continentais/Universidade Estadual de Maringá and CAPES/PROEX for the Zoobenthos Ecology subject and present research.

\section{References}

AGOSTINHO, AA. and ZALEWSKI, M., 1996. A planície alagável do alto rio Paraná: importância e preservação. Maringá: EDUEM. $100 \mathrm{p}$

AGOSTINHO, AA., GOMES, LC., VERÍSSIMO, S. and OKADA, EK., 2004. Flood regime, dam regulation and fish in the Upper Paraná River: effects on assemblage attributes, reproduction and recruitment. Reviews in Fish Biology and Fisheries, vol. 14, p. 11-19. http://dx.doi.org/10.1007/s11160-004-3551-y.

BARLETTA, M., JAUREGUIZAR, AJ., BAIGUN, C., FONTOURA, NF., AGOSTINHO, AA., ALMEIDA-VAL, VM., VAL, AL., TORRES, RA., JIMENES-SEGURA, LF., GIARRIZZO, T., FABRÉ, NN., BATISTA, VS., LASSO, C., TAPHORN, DC., COSTA, MF., CHAVES, PT., VIEIRA, JP. and CORREAA, MF., 2010. Fish and aquatic habitat conservation in South America: a continental overview with emphasis on neotropical systems. Journal of Fish Biology, vol. 76, no. 9, p. 2118-2176. http:// dx.doi.org/10.1111/j.1095-8649.2010.02684.x. PMid:20557657

BEHREND, RD., FERNANDES, SE., FUJITA, DS. and TAKEDA, AM., 2009. Eight years of monitoring aquatic Oligochaeta from the Baía and Ivinhema Rivers. Revista Brasileira de Biologia = Brazilian Journal of Biology, vol. 69, no. 2, suplemento, p. 559-571. http://dx.doi.org/10.1590/S1519-69842009000300011. PMid:19738963

BLETTLER, M., AMSLER, M., DRAGO, IE. and MARCHESE, M., 2008. Effects of stream hydraulics and other environments variables on density of Narapa bonettoi (Oligochaeta) in Paraná River system. River Research and Applications, vol. 24, no. 8, p. 1124-1140. http://dx.doi.org/10.1002/rra.1115.

BOON, PJ., CALLOW, P. and PETS, GE., 1992. River conservation and management. Chichest: Wiley \& Sons. p. 470.

BRINKHURST, RO. and JAMIESON, BMG., 1971. Aquatic Oligochaeta of the world. Edinburgh: Oliver and Boyd. p. 860.

BRINKHURST, RO. and MARCHESE, MR., 1991. Guia para la identificacion de oligoquetos aquáticos continentales de Sudy Centro América. Santo Tomé: Asociación de Ciencias Naturales del Litoral.

DRAGO, IE., 1980. Campaña limnológica Keratella I en el río y ambientes leníticos asociados. Ecología, vol. 4, p. 89-101.

DRAGO, IE., MARCHESE, M. and WANTZEN, M., 2004. Benthos of a large neotropical river: spatial patterns and species assemblage in the Lower Paraguay and its floodplains. Archiv fuer Hydrobiologie, vol. 160, no. 3, p. 347-374. http://dx.doi. org/10.1127/0003-9136/2004/0160-0347.

FURSE, M., HERING, D., MOOG, O., VERDONSCHOT, P., JOHNSON, RK., BRABEC, K., GRITZALIS, K., BUFFAGNI, A., PINTO, P., FRIBERG, N., MURRAY-BLIGH, J., KOKES, J., ALBER, R., USSEGLIO-POLATERA, P., HAASE, P., SWEETING, R., BIS, B., SZOSZKIEWICZ, K., SOSZKA, H., SPRINGE, G., SPORKA, F. and KRNO, I., 2006. The STAR project: context, objectives and approaches. Hydrobiologia, vol. 566, no. 1, p. 3-29. http://dx.doi.org/10.1007/s10750-006-0067-6.

HIGUTI, J. and TAKEDA, AM., 2002. Spatial and temporal variation in of Chironomid larval (Diptera) in two lakes and two tributaries of the Upper Paraná River floodplain, Brazil. Brazilian Journal of Biology, vol. 62, no. 4b, p. 807-818. http://dx.doi. org/10.1590/S1519-69842002000500010.

JESÚS-CRESPO, R. and RAMÍREZ, A., 2011. Effects of urbanization on stream physicochemistry and macroinvertebrate assemblages in a tropical urban watershed in Puerto Rico. Journal of the North American Benthological Society, vol. 30, no. 3, p. 739-750. http://dx.doi.org/10.1899/10-081.1.

KAGALOU, I., ECONOMIDIS, G., LEONARDOS, I. and PAPALOUKAS, C., 2006. Assessment of a Mediterranean shallow lentic ecosystem (Lake Pamvotis, Greece) using benthic community diversity: Response to environmental parameters. Limnologica, vol. 36, no. 4, p. 269-278. http://dx.doi.org/10.1016/j. limno.2006.08.002.

KOWNACKI, A., 1971. Taxocens of Chironomidae in Polish high trataments. Acta Hydrobiologica (Cracow), vol. 13, no. 4, p. 439-464.

MARCHESE, MR., 1987. The ecology of some benthic Oligochaeta from the Paraná River, Argentina. Hydrobiologia, vol. 155, no. 1, p. 209-214. http://dx.doi.org/10.1007/BF00025653.

MARCHESE, M. and DRAGO, IE., 1992. Benthos of the lotic enviroments in the middle Paraná River system: transverse zonation. Hydrobiologia, vol. 237, no. 1, p. 1-13. http://dx.doi. org/10.1007/BF00008422.

MARCHESE, M., 1994. Population dynamics of Narapa bonettoi Righi and Varela, 1983 (Oligochaeta: Narapidae) from the main channel of the middle Paraná River, Argentina. Hydrobiologia, vol. 278, no. 1-3, p. 303-308. http://dx.doi.org/10.1007/BF00142339.

MARCHESE, M., 2009. Annelida Oligochaeta. In DOMÍNGUEZ, E. and FERNÁNDEZ, HR. Macroinvertebrados bentónicos sudamericanos-Sistemática y biologia. Tucumán: Fundación Miguel Lillo. p. 551-565

MONTANHOLI-MARTINS, MC. and TAKEDA, AM., 1999. Communities of benthic oligochaetes in relation to sediment structure in the upper Parana River, Brazil. Studies on Neotropical Fauna and Environment, vol. 34, no. 1, p. 52-58. http://dx.doi. org/10.1076/snfe.34.1.52.8917

MUGNAI, R., NESSIMIAN, JL. and BAPTISTA, DL., 2010. Manual de identificação de macroinvertebrados aquáticos do Estado do Rio de Janeiro. Rio de Janeiro: Technical Books. 173 p.

PAILlEX, A., DOLÉDEC, S., CASTELLA, E., MÉRIGOUX, S. and ALDRIDGE, DC., 2012. Functional diversity in a large river floodplain:anticipating the response of native and alien macroinvertebrates to the restoration of hydrological connectivity. Journal of Applied Ecology, vol. 50, no. 1, p. 97-106. http://dx.doi. org/10.1111/1365-2664.12018.

PÉREZ, GR., 1988. Guía para el estúdio de los macroinvertebradosacuáticos del Departamento de Antioquia. Bogotá: Presencia. 217 p.

PRIMACK, RB., 1993. Essentials of Conservation Biology. Sunderland: Sinauer Associates.

RIBEIRO, ML., BLANCKAERT, K., ROY, AG. and SCHLEISS, AG., 2012. Hydromorphological implications of local tributary widening 
for river rehabilitation. Water Resources Research, vol. 48, no. 10 . article number W10528. http://dx.doi.org/10.1029/2011WR011296.

RIGHI, G. and VARELA, ME., 1983. Narapa bonettoi, gen. nov. sp. Nov. (Oligochaeta, Narapidade, fam. nov.). de a.u. doce da Argentina. Revista de La Associación de Ciencias Naturales del Litoral, vol. 14, p. 7-15.

RIGHI, G., 1984. Oligochaeta. In SCHADEN, R. Manual de identificação de invertebrados límnicos do Brasil. Brasília: CNPq. 48 p.

ROSIN, GC., OLIVEIRA-MANGAROTTI, DP., TAKEDA, AM. and BUTAKKA, CM., 2009. Consequences of dam construction upstream of the Upper Paraná River floodplain (Brazil): a temporal analysis of the Chironomidae community over an eight-year period. Revista Brasileira de Biologia = Brazilian Journal of Biology, vol. 69, no. 2, suplemento, p. 591-608. http://dx.doi.org/10.1590/ S1519-69842009000300014. PMid:19738966

SMITH, RF. and LAMP, WO., 2008. Comparison of insect communities between adjacent headwater and main-stem streams in urban and rural watersheds. Journal of the North American Benthological Society, vol. 27, no. 1, p. 161-175. http://dx.doi. org/10.1899/07-071.1.

STEVAUX, JC. and TAKEDA, AM., 2002. Geomorphological processes related to density and variety of zoobenthic community of the upper Paraná River. Zeitschrift fur Geomorphologie, vol. 129 , p. $143-158$.
TAKEDA, AM., 1999. Oligochaeta community of alluvial Upper Paraná River, Brazil: spatial and temporal distribution (19871988). Hydrobiologia, vol. 412, p. 35-42.

TAKEDA, AM., EDUARDO, C., ROCHA, F. and STEVAUX, JC., 2001a. The influence of water and sediment properties on the occurrence of Potamocaris Dussart, 1979 (Harpacticoida) in the Upper Paraná River (Brazil). Hydrobiologia, vol. 453-454, p. 403-409. http://dx.doi.org/10.1023/A:1013198219922.

TAKEDA, AM., STEVAUX, JC. and FUJTTA, DS., 2001b. Effect of hydraulics, bed load grain size and water factors on habitat and abundance of Narapa bonettoi Righi \& Varela, 1983 of the Upper Paraná River, Brazil. Hydrobiologia, vol. 463, no. 1-3, p. 241-248. http://dx.doi.org/10.1023/A:1013180430540.

WANG, B., LIU, D., LIU, S., ZHANG, Y., LU, D. and WANG, L., 2012. Impacts of urbanization on stream habitats and macroinvertebrate communities in the tributaries of Qiangtang River, China. Hydrobiologia, vol. 680, no. 1, p. 39-51. http:// dx.doi.org/10.1007/s10750-011-0899-6.

WARD, JV. and STANFORD, JA., 1979. Ecological factors controlling stream zoobenthos with emphasis on thermal modification of regulated streams. In WARD, JV. and STANFORD, JA. The ecology of regulated streams. New York: Plenum Publishing. p. 35-56.

WENTWORTH, CK., 1922. A scale of grade and class trems for clastic sediments. The Journal of Geology, vol. 30, no. 5, p. 377-392. http://dx.doi.org/10.1086/622910. 